\title{
Redescription of Hypostomus johnii, a senior synonym of Hypostomus eptingi (Siluriformes: Loricariidae), Northeastern Brazil
}

\author{
Telton Pedro Anselmo Ramos ${ }^{1}$, Claudio Henrique Zawadzki², Robson Tamar da \\ Costa Ramos ${ }^{1}$ and Heraldo Antônio Britski ${ }^{3}$
}

Hypostomus johnii (Steindachner) was described from the rio Parnaíba basin in the state of Piaú and the rio São Francisco basin in the state of Bahia. Despite the good quality of the original description of H. johnii, it does not currently allow its distinction from congeners. Thus, $H$. johnii is redescribed based on the analysis of the types and several recently collected specimens. Recent collecting efforts of the rios Parnaíba and São Francisco basins resulted in specimens only being found in the rio Parnaíba basin. This raises doubts about whether H. johnii occurs in the rio São Francisco basin. The species is distinguished from its congeners by having a high number of teeth on the premaxilla and dentary (between 60-115); small to moderate-sized dark spots with a light background; absence of keels on flanks; and abdominal plates more evident on laterals. A lectotype of $H$. johnii is designated herein and $H$. eptingi is considered a junior synonym of $H$. johnii.

Keywords: Armoured catfish, Freshwater fish, Hypostominae, Neotropical fish, Taxonomy.

Hypostomus johnii (Steindachner) foi descrita a partir de espécimes da bacia do rio Parnaíba, no Estado do Piauí e da bacia do rio São Francisco, no Estado da Bahia. Apesar da descrição original de H. johnii ter sido adequada para a época, esta não permite atualmente a sua diferenciação dos outros congêneres. Portanto, $H$. johnii é redescrita, baseado na análise dos tipos e de espécimes recentemente coletados. Recentes esforços de coleta nas bacias do rios Parnaíba e São Francisco resultaram em espécimes coletados apenas na bacia do rio Parnaíba. Este fato coloca em dúvida a ocorrência de $H$. johnii na bacia do rio São Francisco. Hypostomus johnii é diferenciada de seus congêneres principalmente por possuir um elevado número de dentes no pré-maxilar e dentário (entre 60-115), por apresentar pequenas manchas escuras de tamanho moderado sobre um fundo claro; ausência de quilhas sobre flancos; e as placas do abdômen mais evidente nas laterais. Um lectótipo para $H$. johnii é aqui designado e $H$. eptingi é considerado sinônimo júnior de $H$. johnii.

Palavras-chave: Cascudos, Hypostominae, Peixes de água doce, Peixes Neotropicais, Taxonomia.

\section{Introduction}

Loricariidae is found throughout South America, Panama, and Costa Rica (Armbruster, Page, 2006). The family has about 80 genera and over 800 species (Eschmeyer, Fong, 2015), of which Hypostomus Lacépède, 1803 is its most diverse genus (Isbrücker, 2001; Armbruster, 2004). Hypostomus johnii (Steindachner, 1877) was originally described from rio Poti (a tributary of rio Parnaíba, misspelled in original description as "Puty") and rio Preto (a tributary of rio São Francisco). This accounts for the registered distribution of Hypostomus johnii being considered as occurring in the Parnaíba and São Francisco ecoregions (sensu Abell et al., 2008). The type locality for Hypostomus eptingi (Fowler, 1941) is "Forteleza", in the state of Ceará, Northeastern Caatinga and Coastal Drainage ecoregion (sensu Abell et al., 2008).

Five species of Hypostomus are described from the São Francisco ecoregion: Hypostomus alatus Castelnau (1855) (type locality: Sabará, state of Minas Gerais), Hypostomus francisci (Lütken, 1874) and H. lima (Lütken, 1874) (type locality: from the upper portion of the rio São Francisco basin), Hypostomus vaillanti (Steindachner, 1877) (type locality: rio Preto - at Vila de Santa Rita, a tributary of the rio São Francisco basin, state of Bahia), and Hypostomus garmani (Regan, 1904) (type locality: rio das Velhas).

\footnotetext{
${ }^{1}$ Laboratório de Sistemática e Morfologia de Peixes, Departamento de Sistemática e Ecologia/CCEN, Universidade Federal da Paraíba, Campus I, 58059-900 João Pessoa, PB, Brazil. (TPAR) telton@gmail.com (corresponding author), (RTCR) robtamar@gmail.com ${ }^{2}$ Departamento de Biologia/Núcleo de Pesquisas em Limnologia, Ictiologia e Aquicultura (Nupélia), Universidade Estadual de Maringá, Av. Colombo, 5790, 87020-900 Maringá, PR, Brazil. chazawadzki@hotmail.com

${ }^{3}$ Museu de Zoologia da Universidade de São Paulo, Caixa Postal 42494, Ipiranga, 04299-970 São Paulo, SP, Brazil. heraldo@usp.br
} 
In addition to Hypostomus johnii, specimens of $H$. auroguttatus Kner (1854), H. plecostomus (Linnaeus, 1758 ), and $H$. vaillanti are recorded as occurring in the Parnaíba ecoregion (Eigenmann, Eigenmann, 1890; Regan, 1904; Eigenmann, 1910; Miranda-Ribeiro, 1911; Fowler, 1954; Menezes, 1955; Roberts, 1968; Rosa et al., 2003). The rio Parnaíba is the longest river in Northeastern Brazil, with its drainage extending across the entire region. The river is about $1400 \mathrm{~km}$ long with its hydrographic basin occupying an area of $344,112 \mathrm{~km}^{2}$ (3.9\% of Brazil), draining almost the entire state of Piauí $(99 \%)$ and part of Maranhão (19\%) and Ceará (10\%) states. It is one of the few perennial rivers in the Brazilian Northeastern Region, running predominantly in the Caatinga biome in the east (with intermittent drainages associated with this type of environment), and partly extending into the Cerrado biome in the west (Rosa et al., 2003; Ramos et al., 2014).

Besides Hypostomus eptingi, five other species of Hypostomus are described from the Northeastern Caatinga and Coastal Drainage ecoregion: H. pusarum (Starks,1913) (type locality: rio Ceará-Mirim, state of Rio Grande do Norte), H. jaguribensis (Fowler, 1915) (type locality: rio Jaguaribe, state of Ceará), H. carvalhoi (Miranda-Ribeiro, 1937) (type locality: rio Granjeiro, upper Jaguaribe basin, state of Ceará), H. nudiventris (Fowler, 1941) (type locality: rio Choró, near Fortaleza, state of Ceará), and $H$. papariae (Fowler, 1941) (type locality: Lago Papary, Nísia Floresta, state of Rio Grande do Norte).

Despite the good quality of the original description of Hypostomus johnii, it does not currently allow its distinction from congeners. Thus, Hypostomus johnii is redescribed based on the examination of types and recently collected material, as well as the examination of $H$. eptingi type material, which is conspecific with $H$. johnii. Hence, $H$. eptingi is considered herein as a junior synonym of $H$. johnii.

\section{Materials and Methods}

Specimens were collected and immediately anesthetized with benzocaine and then fixed in formalin for approximately two weeks, thereafter they were transferred to $70 \%$ ethanol. Measurements were taken using a digital caliper according to procedures of Boeseman (1968) and Weber (1985). Descriptions of color patterns were based on observations of physical specimens in the field and/or using photographs taken of live individuals. Measurements are presented as percentages of standard length (SL) or head length (HL). Meristic data were obtained for all specimens available for analysis. Osteological examinations of bone and cartilage were performed on cleared and doublestained specimens according to the procedure of Taylor, Van Dyke (1985).

Institutional abbreviations of the ichthyological collections followed Sabaj-Pérez (2016).

\section{Results}

\section{Hypostomus johnii (Steindachner, 1877)}

(Figs. 1-2, Tab. 1)

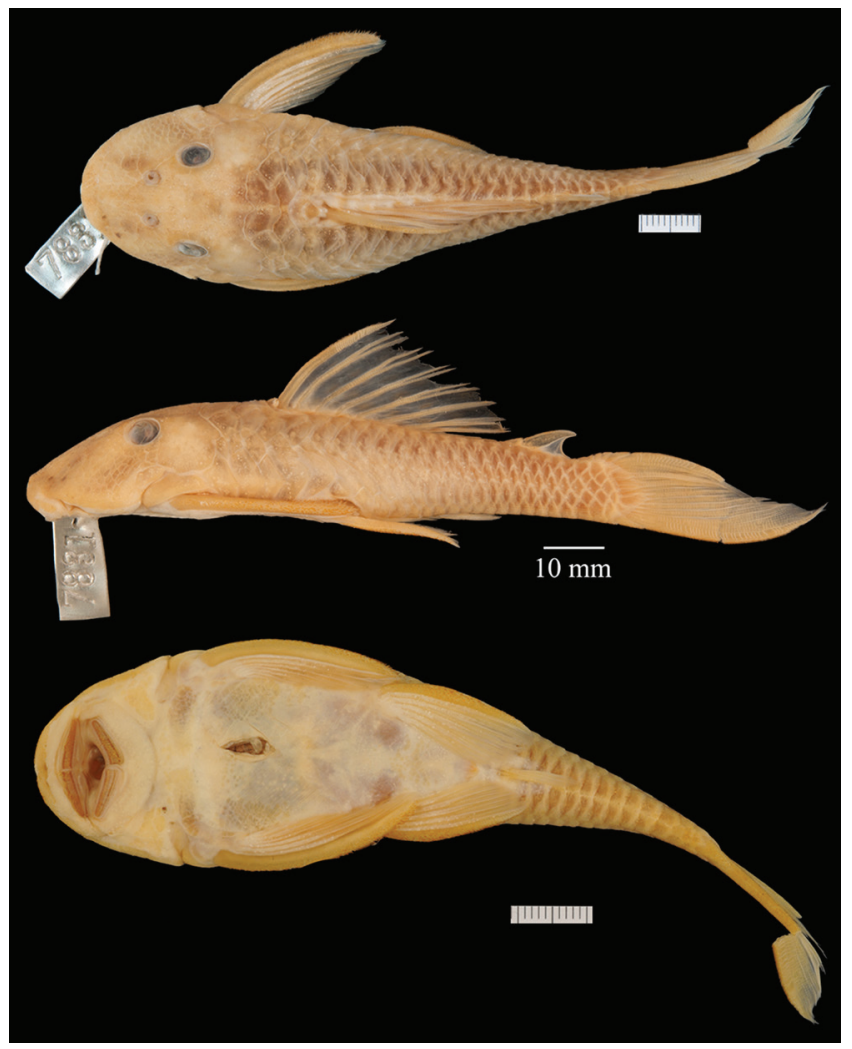

Fig. 1. Hypostomus johnii, lectotype, MCZ 7831, $94.0 \mathrm{~mm}$ SL, Brazil, state of Piauí, municipality of Teresina, rio Poti, tributary of rio Parnaíba. Dorsal, lateral and ventral views. Photo by Museum of Comparative Zoology, Harvard.

Plecostomus johnii Steindachner, 1877: 691. Type locality: rio Puty (misspelling of Poti), Teresina, Piauí, and rio Preto, Vila de Santa Rita (currently municipality of Santa Rita de Cassia), Bahia, Brazil; types (several): MCZ 7831 (1), 7863-64 (4, 2); NMW 44191-93 (2, 2, 2). -Eigenmann, Eigenmann, 1890 (revision).

Plecostomus auroguttatus. -Regan, 1904; Eigenmann, 1910; Miranda-Ribeiro, 1911; Fowler, 1954; Menezes, 1955 (checklist of species). -Rosa et al., 2003 (checklist of species).

Hypostomus johnii (Steindachner, 1877). -Isbrücker, 1980: 25 (new combination). -Burgess, 1989:431 (catalogue of species). -Ferraris, Jr., Vari, 1992:31 (catalogue of species). -Ferraris, Jr., 2007:255 (checklist and catalogue of species). -Isbrücker, 2001:28 (literature compilation). -Isbrücker, 2002:19 (literature compilation). -Reis et al., 2003:359 (checklist of species). -Armbruster, 2004:79 (literature compilation). -Buckup et al., 2007 (catalogue of species). -Garavello et al., 2012 (comparative material). -Montoya-Burgos, 2003 (biogeography). -Zawadzki et al., 2012:246 (comparative material). -Zanata et al., 2013:248 (comparative material). -Ramos et al., 2014 (checklist of species). -Silva et al., 2015 (checklist of species). -Zawadzki 
et al., 2015: 57 (comparative material). -Rodrigues-Filho et al., 2016 (checklist of species). -Zanata, Pitanga, 2016:229 (comparative material).

Chaetostomus eptingi Fowler, 1941: 158, figs. 66-68. Type locality: Forteleza, Ceará [Brazil]. -Gosline, 1945: 94 (checklist of species). -Fowler, 1954:148 (checklist of species). -Isbrücker, 1980: 60 (checklist of species).

Hypostomus eptingi. -Isbrücker, 2001: 28 (new combination). -Weber, 2003:357 (checklist of species). -Reis et al., 2003:359 (checklist of species). -Rosa et al., 2003 (literature compilation). -Armbruster, 2004 (literature compilation). -Buckup et al., 2007 (catalogue of species). -Ferraris, Jr., 2007: 253 (checklist and catalogue of species). -Zanata et al., 2013:248 (comparative material).

Diagnosis. Hypostomus johnii differs from congeners, except $H$. alatus, H. arecuta, H. bolivianus, $H$. chrysostiktos, $H$. denticulatus, H. francisci, $H$. garmani, $H$. isbrueckeri, H. jaguar, H. kuarup, H. latirostris, H. luteomaculatus, $H$. macrops, $H$. meleagris, $H$. multidens, $H$. mutucae, $H$. myersi, $H$. paulinus, $H$. regani, $H$. strigaticeps, $H$. ternetzi, $H$. unae, and $H$. yaku by having high number of teeth on premaxillary (60-110) and dentary (65-115) (vs. fewer teeth on both premaxillary and dentary, rarely more than 50 in the other species). Hypostomus johnii differs from $H$. alatus, $H$. arecuta, $H$. chrysostiktos, $H$. francisci, $H$. luteomaculatus, $H$. meleagris, $H$. multidens, $H$. myersi, $H$. regani, $H$. strigaticeps and $H$. tietensis by having dark brown spots over body and fins (vs. pale spots). Hypostomus johnii differs from $H$. bolivianus by having bicuspid teeth (vs. unicuspid teeth); from $H$. denticulatus by having teeth with asymmetric cusps (vs. teeth with symmetrical cusps); from $H$. isbrueckeri by the presence of homogeneous caudal-fin ground color ( $v s$. a yellow distal band on caudal-fin margin in mature males); from $H$. garmani, $H$. latirostris, $H$. macrops, $H$. ternetzi and $H$. uruguayensis by having abdominal platelets more clustered on laterals of abdomen ( $v s$. abdominal platelets mainly medially clustered) and by having spot diameters from similar to smaller than pupil diameter ( $v S$. spot diameters approximately equal to larger than eye diameter); from $H$. jaguar by having inconspicuous dark spots, its diameter from smaller to equal than pupil diameter ( $v s$. conspicuous dark spots, its diameter from approximately equal to larger than eye diameter); from $H$. kuarup, $H$. mutucae and $H$. unae by the abdominal area from pectoral girdle to the anus covered by dermal plates ( $v s$. abdomen almost naked; with two or more rows of platelets on each side of body between pectoralfin origin and pelvic-fin origin); from $H$. paulinus by having smaller eyes, orbital diameter $12.7-17.2 \%$ in HL and 27.8$45.6 \%$ in interobital width (vs. $17.5-22.1 \%$ and $46.3-67.1 \%$, respectively); from $H$. auroguttatus and $H$. uruguayensis by having one predorsal plate bordering supraoccipital ( $v s$. three predorsal plates bordering supraoccipital); from $H$. yaku by lacking hypertrophied odontodes on flanks ( $v s$. hypertrophied odontodes on flanks, more developed in mature males). Besides the high number of teeth on premaxillary and dentary, Hypostomus johnii further differs from $H$. vaillantii by presenting ventral region of head and abdomen usually without spots, a few dark spots present in some few specimens ( $v s$. ventral region of head and abdomen with spots forming irregular rings, some incomplete) and from $H$. macrops by having smaller eyes, with orbital diameter 12.7-17.2\% HL (vs. 17.5-22.4\%).

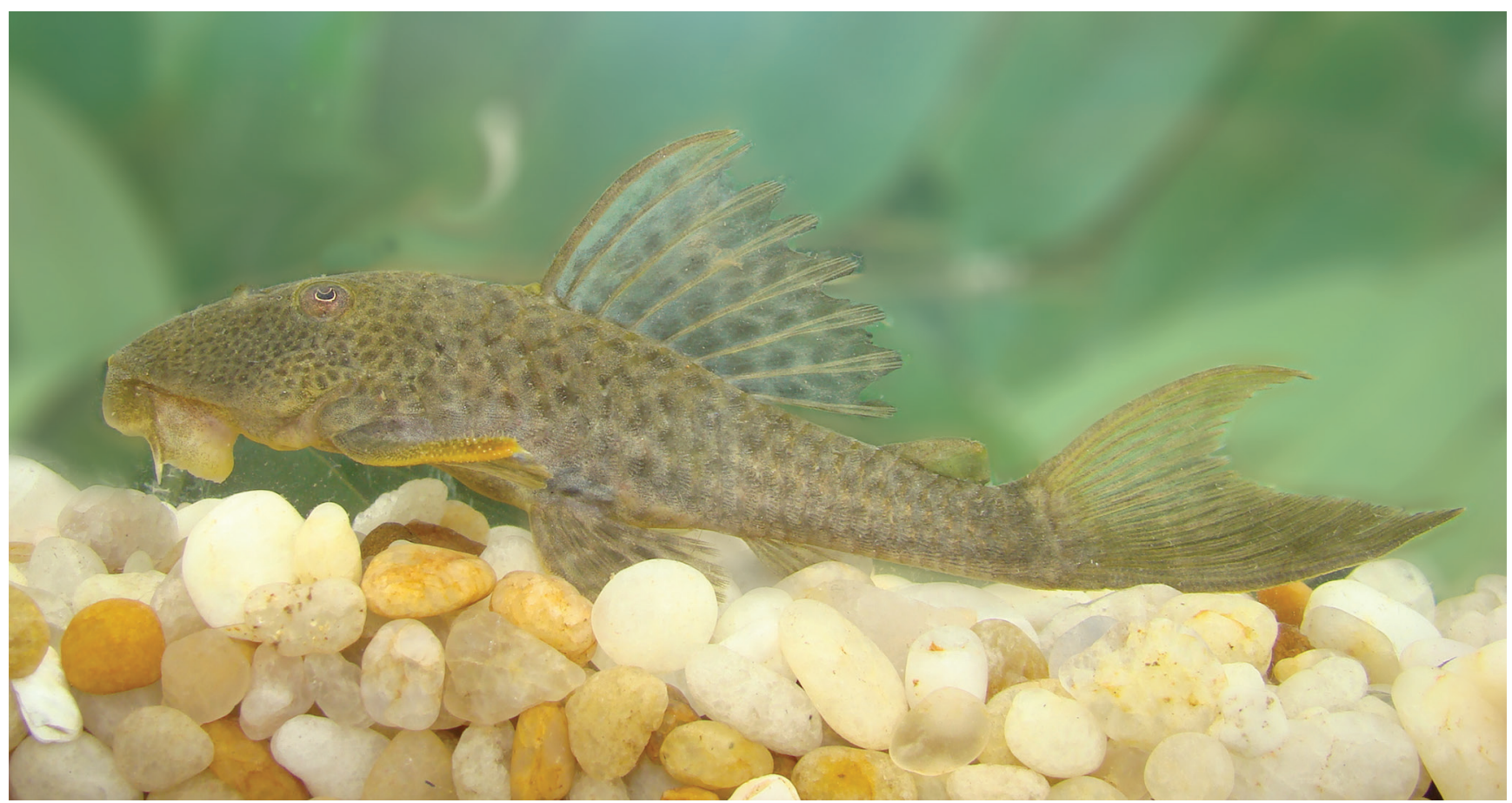

Fig. 2. Photograph of a fresh specimen of Hypostomus johnii (UFRN 1800, $116.0 \mathrm{~mm} \mathrm{SL}$ ) from the rio Guaribas, municipality of Picos, state of Piauí, Brazil (photographed immediately after capture). 
Tab. 1. Morphometric data and counts of Hypostomus johnii from the rio Parnaíba basin, Brazil. N=22; SD, Standard deviation.

\begin{tabular}{|c|c|c|c|c|}
\hline & Lectotype & Range & Mean & SD \\
\hline Standard length (mm) & 94.0 & $82.0-157.2$ & 100.2 & - \\
\hline \multicolumn{5}{|c|}{ Percents of standard length } \\
\hline Predorsal distance & 42.6 & $39.8-44.2$ & 42.3 & 1.1 \\
\hline Head length & 35.1 & $31.5-37.4$ & 34.7 & 1.4 \\
\hline Cleithral width & 33.0 & $31.1-34.8$ & 32.8 & 0.9 \\
\hline Head depth & 18.8 & $17.3-20.1$ & 18.7 & 0.8 \\
\hline Interdorsal length & 16.8 & $15.3-19.0$ & 17.1 & 0.9 \\
\hline Caudal-peduncle length & 30.9 & 29.9-33.6 & 31.4 & 0.9 \\
\hline Caudal-peduncle depth & 9.6 & $9.1-12.0$ & 9.7 & 0.5 \\
\hline Dorsal-spine length & 25.5 & $22.0-30.8$ & 25.7 & 2.0 \\
\hline Thoracic length & 23.0 & $20.0-23.3$ & 21.3 & 0.9 \\
\hline \multicolumn{5}{|c|}{ Percents of head length } \\
\hline Cleithral width & 93.9 & $89.9-99.5$ & 94.3 & 2.4 \\
\hline Head depth & 53.6 & $48.3-60.1$ & 53.8 & 3.0 \\
\hline Snout length & 60.6 & $61.8-66.9$ & 64.8 & 1.3 \\
\hline Orbital diameter & 18.2 & $12.7-17.2$ & 15.3 & 1.3 \\
\hline Interorbital width & 37.6 & $37.4-49.9$ & 40.4 & 2.5 \\
\hline Mandibular width & 25.2 & 19.4-22.9 & 20.9 & 0.9 \\
\hline \multicolumn{5}{|c|}{ Other percents } \\
\hline Orbital diameter in snout length & 30.0 & $20.0-27.0$ & 23.7 & 2.1 \\
\hline Orbital diameter in interorbital width & 48.4 & $27.8-45.6$ & 37.9 & 4.2 \\
\hline First dorsal-fin length in predorsal length & 60.0 & $52.4-75.5$ & 60.9 & 5.2 \\
\hline First pectoral-fin length in predorsal length & 64.0 & $65.1-81.3$ & 72.7 & 4.3 \\
\hline Lower caudal-fin length in predorsal length & 79.0 & $74.0-87.1$ & 80.5 & 5.1 \\
\hline Adipose-fin length in caudal-peduncle depth & 94.7 & $81.7-115.0$ & 97.6 & 8.9 \\
\hline Caudal-peduncle depth in caudal-peduncle length & 32.8 & $27.5-38.5$ & 30.92 & 2.1 \\
\hline Interdorsal length in dorsal-fin base length & 67.8 & $54.7-72.1$ & 65.2 & 5.6 \\
\hline Lower lip width in lower lip length & 66.9 & $43.8-68.3$ & 57.3 & 7.0 \\
\hline \multicolumn{5}{|c|}{ Counts } \\
\hline Median plates series & 25 & $25-26$ & 25 & 2.3 \\
\hline Predorsal plates & 3 & $3-3$ & 3 & - \\
\hline Plates bordering supraoccipital & 1 & $1-1$ & 1 & _- \\
\hline Dorsal plates below dorsal-fin base & 7 & $6-7$ & 7 & 0.2 \\
\hline Plates between dorsal and adipose fin & 6 & $5-7$ & 7 & 0.5 \\
\hline Plates between adipose and caudal fin & 3 & $3-4$ & 4 & 0.4 \\
\hline Plates between end of anal-fin base and caudal fin & 13 & 13 & 13 & - \\
\hline Premaxillary teeth & 62 & $60-110$ & 84 & 14.3 \\
\hline Dentary teeth & - & $65-115$ & 87 & 16.2 \\
\hline
\end{tabular}

Description. Meristic and morphometric data are shown in Tab. 1. Largest specimen examined $157.2 \mathrm{~mm} \mathrm{SL}$. Body moderately long and somewhat depressed. Greatest body width at cleithrum, progressively tapering to end of caudal peduncle; dorsal profile at caudal peduncle slightly concave; ventral region almost straight. Dorsal profile of head from tip of snout to dorsal-fin insertion slightly convex; gently descending straightly from dorsal-fin insertion to caudal peduncle posterior region; ascending again to caudal fin. Head and snout broad and depressed; head covered by dermal bones with odontodes. Mesethmoid forming slight, rounded crest from snout tip to region between nostrils. Orbits laterodorsally positioned on head; orbital diameter
$12.7-17.2 \%$ in HL. Predorsal region formed by three unpaired narrow predorsal plates, with slight keel. Unpaired, elevated nuchal plate in front of dorsal-fin insertion. Dorsal fin II,7; its origin just before vertical through pelvic-fin insertion; dorsal-fin distal border slightly convex. Adipose fin developed and inserted five to six plates after dorsalfin posterior insertion. Pectoral fin I,6; pectoral-fin spine elongate, slightly curved, reaching midlength of pelvic fin and covered by numerous large odontodes. Pelvic fin i,5; unbranched ray slightly curved; reaching anal-fin insertion. Anal fin, i,4; distal border slightly concave. Caudal fin i, 14,i, slightly notched; dorsal unbranched ray longer than unbranched ventral ray. 
Body covered by five lateral series of plates. Dorsal series with keel from its origin to adipose-fin origin. Middorsal series without keel or with an inconspicuous keel. Median series bearing complete lateral line and lacking keel. Lateral line with 25 to 26 plates. Mid-ventral series strongly bent to fourth or fifth plates. Ventral series slightly bent to form flat ventral surface of peduncle region. Tip of snout almost totally covered by platelets. Ventral region of head covered with platelets except beneath lower lip. Scapular bridge covered with platelets except small areas posterior to branchial opening and around pectoral-fin insertion. Abdomen mostly plated in larger specimens, usually irregular distribution of platelets; larger ones next to laterals of abdomen, between pectoral and pelvicfin origins. Naked areas usually caudally to pelvic-fin insertion, and around anus to anal-fin insertion. Oral disk transversely ovate with numerous small papillae; papillae larger proximally to mouth. No hypertrophied medial buccal papilla. Maxillary barbel slightly smaller than orbital diameter. Dentaries long, forming an angle of approximately $140^{\circ}$ to $150^{\circ}$ to each other. Premaxilla with 65-110 and dentary with $65-115$ villiform, bicuspid teeth. Teeth slender, with lanceolate main cusp larger than pointed lateral cusp. Teeth crown bent ventrally.

Coloration. Color of dorsal and lateral body surfaces and fins light brown; head with very closely spaced small, dark spots; trunk with spots slightly larger than on head and forming somewhat longitudinal rows. Interradial membranes of fins, except anal fin, with dark brown spots similar to those of the trunk forming five to eight diagonal lines (from base to distal margin). Anal fin light brown, spots, when present, faint and in low number. Abdominal region light brown; most individuals without spots on abdomen, some with dark brown spots irregularly scattered on entire abdomen; spots absent on ventral surface of caudal peduncle.

Geographical distribution. Specimens of Hypostomus johnii were recently collected in the upper, medium and lower rio Parnaíba basin, states of Ceará, Piauí and Maranhão, Brazil (Fig. 3), occurring mainly in tributaries of the Gurgueia, Poti, Canindé-Piauí and Longá rivers in the state of Piauí.

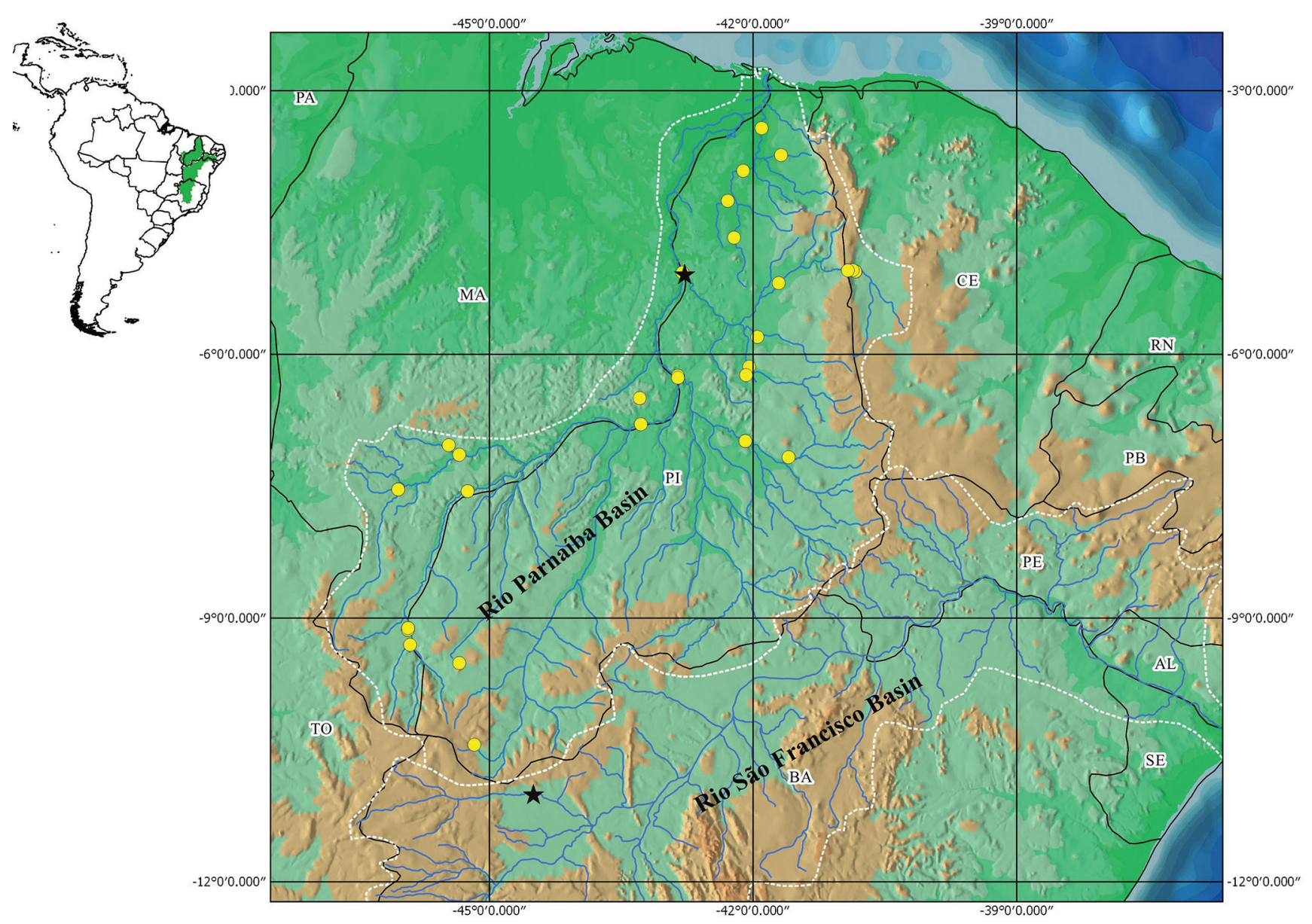

Fig. 3. Geographic distribution of Hypostomus johnii in the rio Parnaíba and São Francisco basins, Northeastern Brazil. Black stars indicates the type locality as Steindachner, 1877 (rio Poti, Teresina, Piauí, Brazil) and rio Preto, Vila de Santa Rita (currently municipality of Santa Rita de Cassia, Bahia, Brazil). 
Ecological notes. In the rio Parnaíba basin, the species usually occurs in areas of moderate current with rocky bottoms and gravel substrates. It has been recorded in co-occurrence with Loricariichthys derbyi Fowler, Parotocinclus haroldoi Garavello, Pterygoplichthys parnaibae (Weber), and an undescribed species of Ancistrus in the rio Poti (type locality). Other co-occurring species are Astyanax aff. bimaculatus, Astyanax aff. fasciatus, Cichlasoma sanctifranciscense Kullander, Compsura heterura Eigenmann, Crenicichla menezesi Ploeg, Hemiodus parnaguae Eigenmann \& Henn, Hoplias malabaricus (Bloch), Leporinus piau Lutken, Phenacogaster calverti (Fowler), Pimelodella parnahybae Fowler, Platydoras brachylecis Piorski, Garavello, Arce H. \& Sabaj Pérez, Potamotrygon signata Garman, Prochilodus lacustris Steindachner, Psectrogaster rhomboides Eigenmann \& Eigenmann, Schizodon rostratus (Borodin), Serrapinnus heterodon (Eigenmann), Serrasalmus rhombeus Lütken, Sternopygus macrurus (Bloch \& Schneider), Synbranchus marmoratus Bloch, Trachelyopterus galeatus (Linnaeus) and Triportheus signatus (Garman).

Conservation status. Considering its broad geographic distribution recently collected in the high, medium and low Parnaíba basin, states of Ceará, Piauí and Maranhão, Brazil, Hypostomus johnii does not match any of the extinction risk categories (IUCN) and for this reason we propose that the species be classified as Least Concern (LC) following the International Union for Conservation of Nature (IUCN) categories and criteria (IUCN Standards and Petitions Subcommittee, 2016).

Material examined. All from Brazil: rio São Francisco basin - State of Bahia. MCZ 7863, 3, 80.0-109.6 mm SL, paralectotype of Plecostomus johnii Steindachner, Vila de Santa Rita (currently municipality of Santa Rita do Rio Preto), rio Preto, tributary of rio São Francisco, 1865, O. St. John. NMW 44191, 2, 105.7-117.4 mm SL, paralectotype of Plecostomus johnii Steindachner; NMW 44192, 2, 88.6-103.5 mm SL, paralectotype of Plecostomus johnii Steindachner; NMW 44193, 2, 94.7-101.4 mm SL, paralectotype of Plecostomus johnii Steindachner, municipality of Vila de Santa Rita (currently municipality of Santa Rita do Rio Preto), rio Preto, tributary of rio São Francisco. rio Parnaíba basin - State of Ceará. UFPB 9266, 4, 97.7$163.6 \mathrm{~mm} \mathrm{SL}$, municipality of Crateus, rio Poti, $05^{\circ} 03^{\prime} 27.5^{\prime}$ 'S 4050'05.1'W, 04 Oct 2012, C. Rezende, L. Macedo \& M. Tavora. UFPB 9267, 5, 92.3-128.7 mm SL, municipality of Crateus, rio Poti, $05^{\circ} 03$ '27.7's 4050'10.8'W, 04 Oct 2012, C. Rezende, L. Macedo \& M. Tavora. UFPB 9268, 1, 109.1 mm SL, municipality of Crateus, rio Poti, $05^{\circ} 02$ '33.9' $\mathrm{S} 40^{\circ} 51^{\prime} 58.6$ ' $\mathrm{W}$, 15 May 2012, C. Rezende, L. Macedo \& M. Tavora. UFPB 9543, 5, 46.5-68.8 mm SL, municipality of Ibiapaba, rio Poti, 0502'42.5'S 4055'16.9'”, 22 Jul 2009, T. P. A. Ramos, P. Honório \& G. Moro. State of Maranhão. NUP 12789, 1, 139.7 mm SL, municipality of São João dos Patos, riacho Quilombo, tributary of rio Parnaíba, 06 $29^{\circ} 54.2^{\prime} \mathrm{S}$ 4317'27.8'W, 18
Jun 2005, W. Severi et al. UFPB 7440, 7, 50.2-141.2 mm SL, municipality of São João dos Patos, rio Quilombo, 06 29' 54.2" S 43¹7'27.8'W, 18 Mar 2005, W. Severi. UFPB 8016, 1, 81.9 mm SL, municipality of São Francisco do Maranhão, rio Parnaíba, 06¹5'55.9'S 4251'21.5'W, 21 Sep 2009, T. P. A. Ramos, M. J. Silva \& G. Moro. State of Piauí. MCZ 7831, 1, $94.0 \mathrm{~mm}$ SL, lectotype of Plecostomus johnii Steindachner, by present designation, municipality of Teresina, rio Poti, tributary of rio Parnaíba, 1865, O. St. John. MCZ 7864, 2, 93.1-95.5 mm SL, paralectotype of Plecostomus johnii Steindachner. MZUSP $36458,1,127.3 \mathrm{~mm}$ SL, municipality of Teresina, mercado de peixes de Teresina, 22 Nov 1985, H. A. Britski. NUP 12789, 1, $139.7 \mathrm{~mm} \mathrm{SL}$, riacho Quilombo, municipality of São João dos

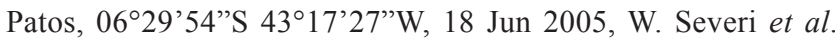
NUP 12790, 1, $91.2 \mathrm{~mm}$ SL, municipality of Juazeiro do Piauí, rio Poti, $05^{\circ} 11$ '21.1'S 4142'31.1'W 19 Jun 2006, W. Severi. NUP 12793, 1, $71.6 \mathrm{~mm}$ SL, municipality of Oeiras, rio Canindé, tributary of rio Parnaíba, 06 59 '12.2”S 42 $05^{\circ} 17.5$ 'W, 21 Jul 2006, W. Severi. UFPB 7441, 2, $73.1 \mathrm{~mm}$ SL, municipality of Juazeiro do Piauí, rio Poti, under a bridge on the PI-115 road, $05^{\circ} 11^{\prime} 21.1^{\prime \prime S} 41^{\circ} 42^{\prime} 31.1$ 'W, 19 Jun 2006,W. Severi. UFPB $7445,4,67.7-78.3 \mathrm{~mm} \mathrm{SL}$, municipality of Oeiras, rio Canindé, 0659'12.2'S 4205'17.5'W, 16 Jul 2006, W. Severi. UFPB $8251,1,122.1 \mathrm{~mm}$ SL, municipality of Floriano, Manga village, rio Parnaíba, 0647'44.1'S 43¹6’39.5'W, 05 Apr 2010, T. P. A. Ramos \& S. A. Q. Ramos. UFPB 9531, 1, 70.7 mm SL, municipality of Aroazes, rio Sambito, tributary of rio Poti, 0608'27.6'S 4202'40.6'W, 10 Sep 2009, T. P. A. Ramos, M. J. Silva \& G. Moro. UFPB 9532, 1, 127.9 mm SL, municipality of Aroazes, rio Sambito, tributary of rio Poti, $06^{\circ} 08^{\prime} 27.6^{\prime \prime} \mathrm{S}$ 42 02'40.6"W, 18 Nov 2009, T. P. A. Ramos \& G. Moro. UFPB 9533, 1, $123.1 \mathrm{~mm}$ SL, municipality of Santa Cruz dos Milagres, rio São Nicolau, 0548'07.6”'S 41 57'06.5”W, 11 Sep 2009, T. P. A. Ramos, M. J. Silva \& G. Moro. UFPB 9534, 6, 66.2-91.6 mm SL, municipality of Picos, Torrões village, rio Guaribas, 07¹0'13.3"S 41³5'49.9'W, 06 Sep 2009, T. P. A. Ramos, M. J. Silva \& G. Moro. UFPB 9535, 18, 56.9-93.7 mm SL, rio Longá, municipality of Nossa Senhora de Nazaré, 0440'20.6"S $42^{\circ} 13^{\prime} 00.5^{\prime}$ W, 23 Jun 2011, T. P. A. Ramos \& S. A. Q. A. Ramos. UFPB 9536, 12, 17.6-86.8 mm SL, municipality of Esperantina, rio Longá, Parque Ecológico Cachoeira do Urubu, 035'43.1"S 4206'47.5"W, 17 Jun 2006, W. Severi. UFPB 9537, 1, $87.1 \mathrm{~mm}$ SL, municipality of Piracuruca, rio Jacaraí, under a bridge on the PI-111 road, $03^{\circ} 44^{\prime} 00.1^{\prime \prime S} 41^{\circ} 40^{\prime} 56.4$ "W, 16 Jun 2006, W. Severi. UFPB 9538, 3, 61.1-68.4 mm SL, municipality of Valença, leaking of Mesa de Pedra Reservoir, rio Sambito, 06¹4'11.4"S 4204'47.4"W, 10 Sep 2009, T. P. A. Ramos, M. J. Silva \& G. Moro. UFPB 9539, 3, 66.2-68.3 mm SL, municipality of Valença, leaking of Mesa de Pedra Reservoir, rio Sambito, 06¹4'11.4"'S 4204'47.4"W, 09 Sep 2009, T. P. A. Ramos, M. J. Silva \& G. Moro. UFPB 9540, 12, 23.3-62.4 mm SL, municipality of Valença, leaking of Mesa de Pedra Reservoir, rio Sambito, 06²1'11.4'’S 4204'47.4'”W, 19 Nov 2009, T. P. A. Ramos, M. J. Silva \& G. Moro. UFPB 9541, 3, 30.9-63.2 mm SL, municipality of Valença, leaking of Mesa de Pedra Reservoir, rio Sambito, 06²1'11.4'S 4204'47.4'”W, 14 Nov 2007, T. P. 
A. Ramos, P. Charvet, R. S. Rosa, C. Wanderlei \& C. Quijada. UFPB 9542, 4, 28.4-65.1 mm SL, municipality of Caxingó, rio Longá, 03²5’35.2”S 4154'12.1”W, 16 Jun 2006, W. Severi. UFPB 9544, 3, 37.1-58.1 mm SL, municipality of Barras, rio Marathoan, tributary of rio Longá, under a bridge on the PI113 road, $04^{\circ} 15^{\prime} 13.0^{\prime}$ 'S $42^{\circ} 17^{\prime} 18.7^{\prime}$ 'W, 16 Jun 2006, W. Severi. UFRN 1233, 32, 30.4-91.7 mm SL, municipality of Aroases, rio Sambito, 06¹'32.1'S 41'59'35.3'W, 24 Mar 2013, S. Lima, T. P. A. Ramos, W. Berbel-Filho, L. Neto, S. Moraes \& A. Moraes. UFRN 1800, 6, 88.5-156.9 mm SL, municipality of Picos, rio Guaribas, 0709'13.3'"S 41³0'10.8' W, 24 Mar 2013, S. Lima, T. P. A. Ramos, W. Berbel-Filho, L. Neto, S. Moraes \& A. Moraes. State of Ceará Fortaleza; ANSP 69447, $122.2 \mathrm{~mm}$ SL, holotype of Chaetostomus eptingi, ANSP 69448, 1, 109.5 mm SL, ANSP 69449, 1, 111.0 mm SL, ANSP 69450, 1, 104.5 $\mathrm{mm}$ SL, paratypes of Chaetostomus eptingi.

\section{Discussion}

The high number of teeth in the upper and lower jaws of Hypostomus johnii (premaxilla 60-110, mode $=84$; and dentary $65-115$, mode 87 ) is the primary distinguishing character of this species from several of its congeners. This feature is especially important when distinguishing H. johnii from other species of Hypostomus occurring in the Northeastern Caatinga and Coastal Drainage ecoregion (sensu Abell et al., 2008). Hypostomus johnii is also distinguishable from its congeners from the rio São Francisco basin by means of coloration: $H$. alatus, $H$. francisci and $H$. cf. margaritifer have pale spots with a darker body and fins, $H$. garmani and $H$. macrops have large dark spots on the body and fins that are larger than eye diameter ( $v s$. dark spots usually smaller than eye diameter). Additionally, the holotype of $H$. macrops (MCZ 7888, $216.0 \mathrm{~mm} \mathrm{SL}$ ) has 50 premaxillary teeth. Hypostomus lima from the rio São Francisco basin is the species most similar to $H$. johnii concerning general color pattern, however, it has a more slender and elongate body compared to $H$. johnii. In addition, the two syntypes of H. lima (BMNH 1896.10.1-2, 73.6-86.1 mm SL) have 4550 dentary teeth and 47-51 premaxillary teeth compared to a higher number of teeth in $H$. johnii. Hypostomus commersoni and $H$. subcarinatus have strong and moderate keels with hypertrophied odontodes along flanks.

The original description and other literature (checklists, catalogues) report Hypostomus johnii as occurring in the rio Preto, a tributary of the rio São Francisco basin, in the state of Bahia, the latter is presumably based on the original description as no voucher specimens have been recorded from the type locality in the state of Bahia since Steindachner's publication. Recent collecting efforts of the rio Preto, including the municipality of Santa Rita de Cassia (formerly known as Santa Rita do Rio Preto during the time of the Thayer Expedition - Dick, 1977; Higuchi, 1996) by researchers from Brazilian institutions (UFPB, UFRN, UFBA, NUP) have resulted in no specimens of
Hypostomus johnii being recorded from the tributary. Thus, the record stating that specimens of $H$. johnii were collected in the rio Preto, rio São Francisco basin, may be a mistake. Additionally, extensive surveys of the Northeastern Caatinga and Coastal Drainage ecoregion (sensu Abell et al., 2008) conducted by the authors of this paper resulted in no specimens of $H$. johnii being recorded. Hence, $H$. johnii may be endemic of Parnaíba basin.

Hypostomus auroguttatus, $H$. plecostomus and H. vaillanti are cited as occurring in the rio Parnaíba (Regan, 1904; Eigenmann, 1910; Miranda-Ribeiro, 1911; Fowler, 1954; Menezes, 1955; Roberts, 1968; Rosa et al., 2003). However, despite extensive sampling of the basin, the occurrence of Hypostomus auroguttatus and $H$. plecostomus was not confirmed (Ramos, 2012; Ramos et al., 2014; Silva et al., 2015), whereas, Hypostomus johnii and $H$. vaillanti were confirmed as occurring in the basin.

The record of Hypostomus auroguttatus occurring in the Parnaíba basin is due to the fact that Regan (1904) considered Plecostomus johnii Steindachner, 1877 as a junior synonym of $P$. auroguttatus Kner, 1854, a decision which was subsequently followed by several authors such as Eigenmann (1910), Miranda- Ribeiro (1911) and Fowler (1954). Isbrücker (1980) proposed a new classification for the Loricariidae and revalidated Plecostomus johnii Steindachner, 1877 as Hypostomus johnii (Steindachner, 1877). Hypostomus johnii differs from $H$. auroguttatus by having a wider, shorter body with dorsal-fin rays reaching pre-adipose plate ( $v s$. thinner and longer body with dorsalfin rays clearly not reaching pre-adipose plate), and by having a single predorsal plate bordeing supraoccipital (vs. three). Chaetostomus eptingi is described based on specimens collected by Rodolpho von Ihering, who made large collections of fishes in Northeastern Brazil between the years of 1936 and 1937. These collections were sent to Henry W. Fowler in 1938 for identification, resulting in a paper being published by Fowler (1941) in which several new species were described, including Chaetostomus eptingi, later referred to as Hypostomus eptingi by Isbrücker (2001: 28).

Chaetostoma eptingi is herein considered as a junior synonym of Hypostomus johnii based on the examination of the holotype (ANSP 69447) and paratypes (ANSP 69448-69450) of the species which matched the description of Hypostomus johnii in all examined features, particularly with regards to the number of pre-maxillary and dentary teeth which varies between 63-70 and 60-80 respectively, and not "35 each side above" and "35 on each mandibular ramus" as mentioned by Fowler (1941: 158).

We would like to state that $H$. johnii was not found in the type locality as described by Fowler (1941: 160) for Chaetostoma eptingi. Besides Chaetostomus eptingi, Fowler (1941) mentioned 32 other species from Fortaleza but we doubt that all these species came from that locality based on two fundamental facts. Firstly, several species 
mentioned by Fowler as occurring in the Fortaleza region where not found, despite intensive collecting efforts (consisting of intensive surveys carried out by the authors of this paper - four expeditions conducted between 2009 and 2013 focused on the creation of a fish manual for the region). The species that were found included the smaller-sized species which are widely distributed throughout Northeastern Brazil. Secondly, some of the species referred to as occurring in Fortaleza are relatively large-sized species (e.g. Pimelodus maculatus, Platydoras costatus, Ageneiosus dentatus, Ageneiosus valenciennesi, Pterygoplichthys lituratus, Prochilodus nigricans, etc.) that inhabit large rivers, which are absent in the Fortaleza area. These circumstances indicate that there may have been some miss labeling related to the species cited for Fortaleza by Fowler (1941). The type locality of Chaetostomus eptingi (= Hypostomus johnii) may not be Fortaleza, and may actually be some other locality in the Parnaiba basin where the occurrence of $H$. johnii was confirmed by voucher specimens and which was exploited by R. von Ihering between the years of 1936 and 1937.

Comparative material examined. All from Brazil. Hypostomus alatus: NUP 9119, 1, $110.1 \mathrm{~mm}$ SL. NUP 9829, 5, 139.0-77.4 mm SL. NUP 9837, 4, 124.4-217.6 mm SL. UFPB 3020, 1, 122.2 mm SL. UFPB 7459, 1, $121.1 \mathrm{~mm}$ SL. Hypostomus brevicauda: BMNH 1864.1.19.16-17, 2, 189.0-196.1 mm SL, syntypes. MCP 36709, 3, 52.7-125.4 mm SL. UFBA 0066, 1, $133.92 \mathrm{~mm}$ SL. UFPB 4541, 15, 140.5-189.2 mm SL. UFPB 4563, 1, $166.9 \mathrm{~mm}$ SL. Hypostomus ef. margaritifer: UFPB 3019, 1, $97.1 \mathrm{~mm} \mathrm{SL}$. UFPB 3041, 1, $97.1 \mathrm{~mm}$ SL. Hypostomus chrysostiktos: UFBA 2787, 3, 160.2-175.4 mm SL. Hypostomus francisci: MCP 14038, 1, $180.0 \mathrm{~mm}$ SL. NUP 9940, 6, 111.0-187.1 mm SL. NUP 9945, 2, 148.6-150.7 mm SL. UFPB 3021, 4, 99.7-115.6 mm SL. Hypostomus garmani: BMNH 1904.1.28.3, holotype, 209.9 mm SL, NUP 9819, 9, 87.7-204.2 mm SL. NUP 10028, 1, $78.8 \mathrm{~mm}$ SL. NUP 10031, 6, 136.6-170.2 mm SL. UFPB 3018, 1, 89.0 mm SL. Hypostomus jaguar: NUP 4448, 2, 126.8-152.9 mm SL. UFBA 6501, 8, 119.21-175.70 mm SL. Hypostomus jaguribensis: UFPB 0053, 4, 40.6-68.1 mm SL; UFPB 0333, 22, 26.5-46.7 mm SL. UFPB 0341, 20, 40.6-68.1 mm SL. UFPB 0793, 1, 51.3 mm SL. UFPB 7699, 1, $101.2 \mathrm{~mm}$ SL. 7700, 6, 81.1-100.8 mm SL. UFPB 9222, 1, $113.4 \mathrm{~mm}$ SL. UFPB 9225, 15, 49.7-86.2 mm SL. UFPB 9226, 1, $140.5 \mathrm{~mm}$ SL. UFRN 0359, 17, 83, 20.2-85.7 mm SL. UFRN 0608, 8, 104.9-184.1 mm SL. UFRN 1168, 8, 72.7-83.7 mm SL. UFRN 1790, 2, 76.9$102.8 \mathrm{~mm}$ SL. UFRN 1813, 1, $75.1 \mathrm{~mm}$ SL. Hypostomus lima: BMNH 1876.1.10, 2, 72.9-86.1 mm SL, syntypes. NUP 5717, 4, 56.1-126.0 mm SL. NUP 5721, 2, 47.5-72.8 mm SL. NUP 9827, 18, 81.5-181.5 mm SL. Hypostomus macrops: NUP 9831, 2, 97.7-106.8 mm SL. NUP 9832, 1, 172.6 mm SL. NUP 9238, 1, 157.9 mm SL. Hypostomus multidens: NUP 5340, 1, 157.0 mm SL. Hypostomus mutucae: MCP 28669, $67.7 \mathrm{~mm}$ SL. NUP 6641, 13, 52.4-109.2 mm SL. NUP 6642, 4, 62.1-98.1 mm SL. Hypostomus nudiventris: ANSP 69402, $56.8 \mathrm{~mm}$ SL, holotype.
NUP 14687, 2, 78.5-100.3 mm SL. UFPB 7697, 3, 78.3$118.4 \mathrm{~mm}$ SL. UFPB 9223, 9, 61.8-74.5 mm SL. Hypostomus papariae: ANSP 69398, 1, $94.3 \mathrm{~mm}$ SL, holotype. ANSP 69399, 1, $99.1 \mathrm{~mm} \mathrm{SL}$, paratype. ANSP 69400, 2, 102.7-126.6 mm SL, paratypes. NUP 14684, 10, 54.6-104.4 mm SL. UFPB 7693, 32, 43.5-72.0 mm SL. Hypostomus paulinus. NUP 5344, 1, $69.0 \mathrm{~mm}$ SL. NUP 5379, 2, 84.1-91.7 mm SL. NUP 5722, 1, $90.5 \mathrm{~mm}$ SL. NUP 6411, 17, 46.5-103.28 mm SL. NUP 6413, 13, 45.9-98.9 mm SL. Hypostomus pusarum: CAS 122221, 4, 94.4-141.7 m. SL, paratypes. CAS 122225, 1, $142.6 \mathrm{~mm} \mathrm{SL}$, holotype. NUP 4795, 11, 140.0-207.0 mm SL. NUP 14683, 2, 103.1-135 mm SL. NUP 14685, 10, 64.7-180.3 mm SL. UFPB 7701, 25, 85.7-174.1 mm SL. UFRN 1818, 6, 88.4-141.3 mm SL. Hypostomus regani: BMNH 1905.6.7.3, 1, 174.2 mm SL, holotype. Hypostomus strigaticeps: BMNH 1907.7.6.1012, syntypes, 3, 75.7-160.0 mm SL. NUP 4017, 2, 72.8-100.0 mm SL. NUP 4538, 11, 82.0-140 mm SL. Hypostomus unae: MCP 41334, 3, 55.2-120.8 mm SL. MCP 41473, 10, 80.2-126.5 mm SL. NUP 9811, 5, 78.9-53.7 mm SL. NUP 9814, 81.5-102.7 mm SL. Hypostomus vaillanti: NMW 44273, 1, $130.5 \mathrm{~mm}$ SL, syntype. NMW 44277, 1, 168.8 mm SL, syntype. NMW 44276, 3, 75.8- 119.4 mm SL, syntypes. MCZ 7842, 2, 121.4- 140.8 mm SL, type. MCZ 7817, 1, 113.4 mm SL. MCZ 7833, 1, 192.0 mm SL. UFBA 4740, 3, 46.4-66.2 mm SL. UFBA 4742, 7, 74.5$118.1 \mathrm{~mm}$ SL. UFBA 6099, 6, 52.3-120.4 mm SL. UFBA 6128, 3, 40.6-89 mm SL. Hypostomus yaku: NUP 15348, 6, 29.8-58.1 $\mathrm{mm}$ SL.

\section{Acknowledgments}

The authors thank all research colleagues who participated in the field work: Airton Carvalho, Dirceu Baumgarnter, Elton França, Guilherme Moro, Ludmila Antunes, Márcio Silva, Patrícia Charvet, Paula Honório, Sergio Lima, Stéfane Ramos, Tiago Debona, Willian Severi, and all local fishermen. Thanks also to Mark Sabaj and John Lundberg (ANSP), Patrick Campbell (BMNH), David Catania, William Eschmeyer and Tomio Iwamoto (CAS), Kevin Swagel and Mary Anne Rogers (FMNH), Paulo Buckup and Marcelo Britto (MNRJ), Margarete Lucena and Roberto Reis (MCP), Kevin Swegel (MCZ), Karsten Hartel and Andrew Williston (MCZ), José Lima Figueiredo and Osvaldo Oyakawa (MZUSP), and Helmut Wellendorf (NMW) for loan of comparative material and hosting museum visits. Visits to museum collections by CHZ were funded by the All Catfish Species Inventory (DEB-0315963). The authors also thank Sarah Viana (IBUSP) for suggestions and comments, and Mark Lisher (SAIAB) for extensive reviewing of this manuscript. This study was supported by CNPq (Conselho Nacional de Desenvolvimento Científico e Tecnológico). CHZ was funded by CNPq Proc. 310733/2013-8. Collections were made under permit 20088-3/2009 MMA/ICMBio/SISBIO from Ministério do Meio Ambiente/Instituto Chico Mendes de Conservação da Biodiversidade/Sistema de Autorização e Informação em Biodiversidade. 


\section{References}

Abell R, Thieme ML, Revenga C, Bryer M, Kottelat M, Bogutskaya $\mathrm{N}$, et al. Freshwater ecoregions of the world: a new map of biogeographic units for freshwater biodiversity conservation. BioScience. 2008; 58(5):403-14.

Armbruster JW. Phylogenetic relationships of the suckermouth armoured catfishes (Loricariidae) with emphasis on the Hypostominae and the Ancistrinae. Zool J Linn Soc. 2004; 141(1):1-80.

Armbruster JW, Page LM. Redescription of Pterygoplichthys punctatus and description of a new species of Pterygoplichthys (Siluriformes: Loricariidae). Neotrop Ichthyol. 2006; 4(4):401-10.

Boeseman M. The genus Hypostomus Lacépède, 1803, and its Surinam representatives (Siluriformes, Loricariidae). Zool Verhandel. 1968; 99:1-89.

Buckup PA, Menezes NA, Ghazzi MS, editors. Catálogo das espécies de peixes de água doce do Brasil. Rio de Janeiro: Museu Nacional; 2007. (Série Livros; 23).

Burgess WE. An atlas of freshwater and marine catfishes. A preliminary survey of the Siluriformes. Neptune City: TFH Publications, Inc.; 1989.

Castelnau FL. Poisson. In: Bertrand P, editor. Animaux nouveaux ou rares recueillis pendant l'expédition dans les partes Centrales de l'Amérique du Sud, de Rio de Janeiro a Lima, et de Lima au Pará; exécutée par ordre du gouvernement Français pendant les années 1843 a 1847. Paris; 1855. pt. 7, Zoologie:p.xii+112.

Dick MM. Stations of the Thayer Expedition to Brazil 18651866. Breviora. 1977; 444:1-37.

Eigenmann $\mathrm{CH}$. Catalogue of the fresh water fishes of tropical and south temperate America. In: Scott, WB, editor. Reports of the Princeton University expeditions to Patagonia 18961899. Princeton: Princeton University; 1910. vol. 3, Zöology, pt. 4 ; p.375-511.

Eigenmann CH, Eigenmann RS. A revision of the South American Nematognathi or cat-fishes. Occas Pap Calif Acad Sci.1890; July(1):1-508.

Eschmeyer WN, Fong JD. Species by family/subfamily in the Catalog of Fishes. [Electronic version]. San Francisco (CA): California Academy of Sciences; 2015. [2016 Oct 01]. Available from: http://research.calacademy.org/research/ ichthyology/catalog/SpeciesByFamily.asp

Ferraris CJ, Jr. Checklist of catfishes, recent and fossil (Osteichthyes: Siluriformes), and catalogue of Siluriform primary types. Zootaxa. 2007; 1418:1-628.

Ferraris CJ, Jr., Vari RP. Catalog of type specimens of recent fishes in the National Museum of Natural History, Smithsonian Institution, 4: Gonorynchiformes, Gymnotiformes, and Siluriformes (Teleostei: Ostariophysi). Washington (DC); Smithsonian Institution Press; 1992. (Smithsonian Contributions to Zoology; no 535).

Fowler HW. Cold-blooded vertebrates from Florida, the West Indies, Costa Rica, and eastern Brazil. Proc Acad Nat Sci Philadelphia. 1915; 67:244-69.
Fowler HW. A collection of fresh-water fishes obtained in eastern Brazil by Dr. Rodolpho von Ihering. Proc Acad Nat Sci Philadelphia. 1941; 93:123-99.

Fowler HW. Os peixes de água doce do Brasil. Arquivos de Zoologia do Estado de São Paulo. 1954; 9:1-400.

Garavello JC, Britski HA, Zawadzki CH. The cascudos of the genus Hypostomus Lacépède (Ostariophysi: Loricariidae) from the rio Iguaçu basin. Neotrop Ichthyol. 2012; 10(2):263-83.

Gosline WA. Catálogo dos Nematognatos de água-doce da América do Sul e Central. Bol. Rio de Janeiro: Museu Nacional; 1945. (Museu Nacional, Boletim, Zoologia, Nova Serie; 33).

Higuchi H. An updated list of ichthyological collecting stations of the Thayer expedition to Brazil (1865-1866). Cambridge (MA): Museum of Comparative Zoology. 1996. Available from: http://www.mcz.harvard.edu/Departments/Ichthyology/ docs/Higuchi_1996_Thayer_Formated_prelim.pdf

Isbrücker IJH. Classification and catalogue of the mailed Loricariidae (Pisces, Siluriformes). Verslagen en Technische Gegevens, Instituut voor Taxonomische Zoöogie, Universiteit van Amsterdam. 1980; $\operatorname{March}(22): 1-181$.

Isbrücker IJH. Nomenklator der Gattungen und Arten der Harnischwelse, Familie Loricariidae Rafinesque, 1815 (Teleostei, Ostariophysi). Die Aquarienzeitschrift (DATZ SonderheftHarnischwelse). 2001; 2:25-32.

Isbrücker IJH. Nomenclator of the 108 genera with 692 species of the mailed catfishes, Family Loricariidae Rafinesque, 1815 (Teleostei, Ostariophysi). Cat Chat, Journal of the catfish study group (UK). 2002; 3(1):11-30.

Lütken CF. Siluridae novae Brasiliae centralis a clarissimo J. Reinhardt in provincia Minas-geraës circa oppidulum Lagoa Santa, praecipue in flumine Rio das Velhas et affluentibus collectae, secundum caracteres essentiales, breviter descriptae. Overs Danske Vidensk Selsk Forhandl Kjobenhavn. 1874; 29-36.

Menezes RS. Lista de peixes de água doce do Piauí. In: Porto CE, editor. Roteiro do Piauí. Rio de Janeiro: Ministério da Educação e Cultura. Ilus. 1955.

Miranda-Ribeiro A. Fauna Brasiliense: Peixes: Tomo IV (A). [Eleutherobranchios Aspirophoros]. Arq Mus Nac. 1911; 16:1-504.

Miranda-Ribeiro A. Sobre uma collecção de vertebrados do nordeste brasileiro. Primeira parte: Peixes e Batrachios. O Campo. 1937; 8(85):54-56.

Montoya-Burgos JI. Historical biogeography of the catfish genus Hypostomus (Siluriformes: Loricariidae), with implications on the diversification of Neotropical ichthyofauna. Mol Ecol. 2003; 12(7):1855-67.

Ramos TPA. Ictiofauna de água doce da bacia do rio Parnaíba. [PhD Thesis]. João Pessoa, PB: Universidade Federal da Paraíba; 2012.

Ramos TPA, Ramos RTC, Ramos SAQA. Ichthyofauna of the Parnaíba River basin, Northeastern Brazil. Biota Neotropica. 2014; 14(1):e20130039.

Regan CT. A monograph of the fishes of the family Loricariidae. Trans Zool Soc London. 1904; 17(3):191-350. 
Reis RE, Kullander SO, Ferraris CJ, Jr. organizers. Check list of the freshwater fishes of South and Central America. Porto Alegre: Edipucrs; 2003.

Roberts TR. The fishes of the Rio Parnaíba. Fortaleza; 1968.

Rodrigues-Filho CAS, Gurgel-Lourenço RC, Bezerra LAV, Sousa WA, Garcez DS, Lima SMQ, Ramos TPA, Sánchez-Botero JI. Ichthyofauna of the humid forest enclaves in the tablelands of Ibiapaba and Araripe, Northeastern Brazil. Biota Neotropica. 2016; 16(4):e20160273.

Rosa RS, Menezes NA, Britski HA, Costa WJEM, Groth F. Diversidade, padrões de distribuição e conservação dos peixes da Caatinga. In: Leal IR, Tabarelli M, Silva JMC, editores. Ecologia e Conservação da Caatinga. Recife: Editora da Universidade Federal de Pernambuco; 2003. p.135-181.

Sabaj-Pérez MH. Standard symbolic codes for institutional resource collections in herpetology and ichthyology. Washington (DC): American Society of Ichthyologists and Herpetologists .Version 6.5. [Internet]; 2016. [updated 2016 Aug]. Available from: http://www.asih.org/sites/default/files/ documents/symbolic_codes_for_collections_v6.5_2016.pdf

Silva MJ, Costa BG, Ramos TPA, Auricchio P, Lima SMQ. Ichthyofauna of the Gurgueia River, Parnaíba River basin, northeastern Brazil. Check List. 2015; 11(5):1765.

Starks EC. The fishes of the Stanford expedition to Brazil. California: Stanford University; 1913.

Steindachner F. Die Süsswasserfische des südöstlichen Brasilien (III). Sitzungsberichte Kaiserl Akad Wiss, Wien. 1877; 74:559-694.

Taylor WR, Van Dyke GC. Revised procedures for staining and clearing small fishes and other vertebrates for bone and cartilage study. Cybium. 1985; 9(2):107-19.
Weber C. Hypostomus dlouhyi, nouvelle espèce de poisson-chat cuirassé du Paraguay (Pisces, Siluriformes, Loricariidae). Rev Suisse Zool. 1985; 92(4):955-68.

Weber C. Subfamily Hypostominae (Armored catfishes). In: Reis RE, Kullander SO, Ferraris CJ, Jr., organizers. Check list of the Freshwater Fishes of South and Central America. Porto Alegre: Edipucrs; 2003. p.351-372.

Zanata AM; Pitanga BR. A new species of Hypostomus Lacépède, 1803 (Siluriformes: Loricariidae) from rio Itapicuru basin, Bahia State, Brazil. Zootaxa. 2016; 4137(2):223-32.

Zanata AM, Sardeiro B, Zawadzki CH. A new dark-dotted species of Hypostomus Lacépède (Siluriformes: Loricariidae) from rio Paraguaçu, Bahia State, Brazil. Neotrop Ichthyol. 2013; 11(2):247-56.

Zawadzki CH, Birindelli JLO, Lima FCT. A new armored catfish species of the genus Hypostomus Lacépède, 1803 (Siluriformes: Loricariidae) from the upper rio Xingu basin, Brazil. Neotrop Ichthyol. 2012; 10(2):245-53.

Zawadzki CH, Oliveira AS, Oliveira RR, Rapp Py-Daniel L. Hypostomus melanephelis, a new armored catfish species from the rio Tapajós basin, Brazil (Teleostei: Loricariidae). Ichthyol Explor Freshw. 2015; 26(1):49-58.

Submitted May 18, 2016

Accepted June 5, 2017 by Javier Maldonado-Ocampo 